\title{
Alienation in the Letters of AL- MA'ARRI, (RESALAT ALHANA') as a Model
}

\author{
Dr._Fatima H. Assarahneh. \\ The Hashemite University \\ Jordan
}

\begin{abstract}
Talking about the literature of $A B U A L A^{\prime} A L-M A^{\prime} A R R I$ cannot be confined to a certain direction, or framed within a certain chapter, because his literature has many features that make it subject to possible interpretations, study and reconsideration. However, AL-MA'ARRI, and through his writings, used his pen as a painter's brush that translates facts as he feels and senses them. His main concern was to portray the reality of things and draw in its setting in an era characterized by fighting, political and religious strife, and internal disruption, in addition to the physical and spiritual sufferings of AL-MA'ARRI, all of them were a source of his self-alienation, so, he suffered alienation of both the place and the body, where, he lived in isolation away from people, abstaining from temptations oftransient worldly possessions, his intellectual and linguistic alienationwasembodied in his prose works, including: (RESALAT ALHANA')

Sometimes, the creative spirit of man staggers at the first tragedy met, or otherwise, it may withstand the shock, and never surrender to the people. In his alienation, AL-MA'ARRI was very strong, bold, and keen on the interest of the nation, he sought change and improvement, and aimed to criticize the decision-makers with caution, because he feared assassination by the authority.
\end{abstract}

\section{Introduction:}

RESALAT ALHANA' is considered one of the most important works of ABU ALA' AL-MA'ARRI, who wasknown as "the Knight of prose and poetry" (MACKIE 1965/351), and reading his literature is a sort of diving into his deep thoughts that do not reveal the hidden.

However, the critical studies revealed their lack of knowledge inAL- MA'ARRI's literature and especially his correspondences, evidenced by the large number of studies and inability to reach the AL- MA'ARRI intention behind them. This study is concerned with reading RESALAT ALHANA' of AL-MA'ARRI and tracing the features of alienation and its motives therein.

RESALAT ALHNA' is based on a number of paradoxes and puzzles, where AL- MA'ARRI practiced a sort of camouflage, It is part of the closed discourses the case with most of AL-MA'ARRI prosewritings,namely, it is not available for public reception, hence the network of symbols in the letter body makes it difficult to interpret unless the reader has inserted the relationship between the sender and the recipient.

This study intended to trace the concept of alienation,studythe motives of alienation with ABU ALA AL-MA'ARRI, Read RESALAT ALHANA' and reveal its dimensions of sender and recipient and the subject of the literary message, all that in order to know about the features of alienation withAL- MA'ARRI.

The study benefited from the cultural approach, "a branch of the general text criticism",thus it'sone ofthe linguistics and the linguistic field concerned with criticizing the implicit formats involved in the cultural discourse with all its manifestations, patterns, and formulas" (ALGHATHAMI, 2014,83 -84).

\section{First: The Concept of Alienation:}

The word "Alienation" received great attention and diversity according to the science it'ssubjected to and complied with,so, it has numerousimplications due to numerous use of this word, as this word has been used in religion, sociology, psychology, law, literature and others.

Alienationwas associated with the psychological and social context, when the individual feels isolation and being outcast from society for violating the social norms, while the legal-psychologicalassociateswith absent-mindedness, lack of awareness and psychological disorders, and classified as a mental diseasesothe individual becomes unable to use his mind, and in the religious context, alienation ismeans falling in sins and committing guilt to be far from Allah,and, in the moral context it's exemplified inpaying tribute to the past and its veneration, and live in a state of alienation from the current time or age(ALJAMAEE, 2007, 39). 
Moreover, alienation is considered one of the human life aspects that accompanied mankind since the earliest ages...it may come as aresult of internal sense of organic cause, it'sa mere illusion that propositions the imagination of person suffering it beyond hiscapacity."(AL JABRI,ALI,2005, 54).

In the Arab Tongue dictionary (LISANALArab), the root of alienation in Arabic "غرب" means "go and step away from

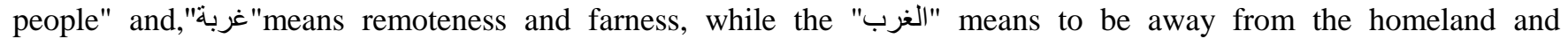
displacement, and "غرب" is farness and strangeness,(IBN MANZOUR, w/o date, material"). However, in AL WASEET lexicon "غرب" meansbe away from homeland, and wentwest means hemoved and became a stranger,and it is said in Arabic "رمي فأغرب" means he shot very far. (ANISE et al., 1972, p. 647)

Furthermore, the ancient Arab heritage entertainspsycho-social alienation beginning with Arab poetry throughto mysticism. Thisstate of the writer is due to hisfeeling that his life is strange as if it was borrowed,alienation is clear in its connotation in the literature of ALTAWHIDI, especially in his known book :" The divine signs", so the type of alienationhe lived is similar to the feeling of being pulled out, due to his repeated sufferingsand ordeals, and he reached inhis strangeness with the people: "so he does not follow theirstereotyped common views, and noradopt their current beliefs", (RAJAB, 1993,41-43)

Others consideredthe alienation of ownership associated withthe unfortunate man for his poverty,then the aliens are those who are "poor destitutewith no worldly fortune and, this means that separation inthe sense of losingman of control over property, is an indication to a state of man alienation states" (SHATA, 1984, 25)

In this vein, HEGELwho is considered the father ofalienationthinks that "alienation is an existential deeply rootedfactin the existence of man,in this world, thusseparation is inherited between the individual, as beinga subject and between the individual as an object, i.e. between the individual as being a creative innovativesubject aspires to be and achieve itself, and between the individual as being an objectsubject to influenceof others and making use of it,thereforethe innovations of the creative individual (Art- language- science and others) stand outside his self and as being strange things, and materialbearingsfor what is essential and a priori, namely, mind and self-consciousness of the individual" (ALMOHAMMADI 2008, 15)

\section{Second: Alienationmotives withABU ALA AL-MA'ARRI:}

Alienation withAL- MA'ARRI has its own motives, as it attaches in one of its dimensions with external factors hence it relates to bad political, economic and social situations, yet, themost important motiveblends withthe blind ALMA'ARRI, who was imprisoned in his house, and called himself (the hostage of two prisons)

\section{First: External motives:}

\section{A. Poor political, social and economic conditions:}

The era of ABU ALA AL- MA'ARRI witnessed many anxious and troubled political events, where he was born in the second half of the fourth century AH, in 363, and lived up to $449 \mathrm{AH}$ wherewitnessedthe age in which a number of caliphs controlled and governed, such as $A L T A E E B E L L A H$ who died in prison after being removed, and $A L Q A D E R$ $B E L L A H$ who was appointed by the state of the BUHAYYAH Stateafter AL TAEE BELLAH, and he was followed by AL KAEM BEAMER ALLAH (AL HAMAWI, 1991, 12)

This political chaos has had a clear role in the dissemination of political turmoil, which has been described by TAHA HUSSEIN saying: "If you read history at that era,you will not come across a day without a state being crushed, a kingdom being annihilated, a human being killedor blood being shed" (HUSSEIN, 1977, 9).

It is worth mentioning that the Islamic world in the time of ABU ALA AL- MA'ARRI was divided into small states and emirates separate from the Abbasid Caliphate.The most important of these states are the DAILYM state in Baghdad, ALHAMDANI state in Aleppo, and the Fatimid state in Egypt (HUSSEIN, 1977, 47)

Thus, the emirate of Aleppo, to which ALMARAAwas affiliated, was prone to cracking, apparent conflict between ALHAMDANYEN and the FATIMIDS on the one hand, and between the nomadic tribes and the Romans on the other hand. However, AL- MA'ARRI era saw major political events, and the state became a scene forunending political strife, conspiracies and wars, and such events reflected onMA'ARAT AL NU'MAN, where ALHAMDANIAstate collapsed bythe death of SAEED AL DAWLA BIN SAAD AL DAWLABIN SEF AL DAWLA, henceALMARDASIYA State controlled it. (DAIF, 1990, 5/333-341), and (HUSSEIN, 1977, 63)

\section{Second: Subjective motives:}

The circumstances of ABU ALA AL- MA'ARRI life had clear role in his asceticism and seclusion from the world lifeand pleasures. He cooked lentils if cooked, figs ashis sweet, clothes are coarse, and his bed of matted wool in winter. All his yearly income was thirty dinars, half of which for his servant and the other half for his victuals(AL KAFTY, 31, 1965) 
Perhaps his blindness had affected his life; hehad a sunken eye and the other vestigial, withpockmarked face.IBN FADLALLAH AL-AMRI said in describing him: "herejected the world and surrenderedand imposed its objectives so he applied what he learned, treated with despair from its greediness, and averted the peopleby quitting his luck to them,and despite of that he was treated unjustly, he rejected world and itsinhabitants, devalued itsbeauties andhe lived in his house in ALMARAAfrom which he had not come out but for his mosque, and hadn't approached a path butfor his night prayer, and convinced himself of conviction that protected him from avidity, and strengthened him against the avarices of the covetous " (IBN FADLULLAH AL-AMRI, 1965, 217 )

The death of his mother, when he was in Baghdad, had a great impact on his life,"he began to feel that he was like a dead strewn twig with no roots and branches:so he decided to withdraw into his prison, not to marry or to have children and thushis parents had died, and he was severed from his roots and sooner or later life water will dry up in him" (ABDEL RAHMAN, 1976, 165)

Owing to life conditions that surrounded AL- MA'ARRI heimprisoned himself in three prisons: "prison of his soul in his body, prisonof his house and prison of hisblindness, and he spent about fifty years for writing his LIZOMEYAT and authoring his great books" (DAIF, 1990, 167)

And thus,such life overshadowed ABU ALA AL- MA'ARRI literary spirit;sosometimes he appearedangryand other time reconciled with himself, butalways aspiring for change and improvement.

\section{Third: Alienation aspects in the letter of RESALAT ALHANA':}

\section{Alienation and title of ALHANA' letter:}

Ambiguity and confusion are a sense prevailing RESALAT ALHANA', where atthe first word threshold, and the title of letter, there increases the sense ofpuzzledfeeling, as ALHANA' isa word that brings together the essence of human life, and confined to the constant desire for happiness, and also coupled with joy and happiness, and linked withwelfare and peace of mind.

However, ALHANA'can be seen differently in the letter titlefilled with paradoxes;so it's subject to the historical context, harbored into it implied patterns connected with AL- MA'ARRI reality and his own vision of the lived through historical era,characters of his time, and reality of his society.

The title of letter suggests the interaction ofAL- MA'ARRI with his time events, where AL- MA'ARRI stared to form a ritual embodiesthe voice of alien toward his different experiences by resorting to the word ALHANA'to make the irony, and expose his reality, and thusAL- MA'ARRI hadpossessed the language competency, "he has his own concepts, grammar, connotations and his own language " (AL-ALAYLEE, 1981, 51)

He says in the opening of the letter: "HANA', coupled with light and illumination, good and splendor, butcongratulations compelany the spiteful the offensive.

These congratulations continue, following one anotherto the long livedmaster, and survived and remained inhappy luck, mountain MATALEI (a BADIA maintain) had ever lasted for ever to stay as long as this mortal world would last"( AL- MA'ARRI, 1982, 71-72)

\section{Centralization of praise action and the intellectual alienation:}

\section{AL- MA'ARRI Between absence and appearance:}

The art of letters is considered an independent literary form (VINCENT, 1958, footnote p. 166), it is a literary form that was characterized by variation; due to its approach that is based on the sender and the recipient to achieve interaction and communication.

AL- MA'ARRI Begins his letter ALHANA' by congratulating thestate consultant masters, then this letter as it appears to its reader "a letter sent by ABU ALA AL- MA'ARRIto some of his great seniorcontemporariesin which he congratulated them of the Sultan's minister arrival"SHEBL AL DAWLA" and calling on him" (AL - MA'ARRI, 1982, p. 3)

In this communicative circle, the sender AL- MA'ARRI,and the recipient, one of the seniorhosting people (Unnamed), and the occasion is the arrival of the the majesty ally (unnamed guest) and calling on him during the time of the MERDASIAstate, and specifically at the timeof (SHEBL AL DAWLA) ABU KAMEL NASR BIN SALEH BIN MIRDAS in MAARAT AL-NU'MAN.

And, the ministers of state are linked to sovereignty and authority, whom AL- MA'ARRI praisesand elevates respectfully,this would acquaint at the centrality of praise action in AL- MA'ARRI letters, and what settled in their words, where adeep philosophy in concealed behind, and a revelation contradictory in its details and traits, also there disappears behind a world of sanity and self-protection, and hints to the coming despotism of the other. 
Thus the ritual of praise in the culture AL- MA'ARRI is an aesthetic tool thatfascinates the power and swindlesitabout his retreat before it, so he deceives it, and divulges the weakness therein starts revealing its weaknesses, and,faces its injustice. So, AL- MA'ARRI makes himself a model that reflects the images of classes and manifestations of social injustice,he says against the praised master: "he enjoys both stateshappiness and congratulations, his face is colored withHENNAanindication of the beauty redness, he is pigmented with HENNA (indicative to his face beauty) "(ALMA'ARRI, 1982, 72 ).

AL- MA'ARRI is not satisfied with praises in the introduction of the letter, but also elicits apology from the praised, because he does not deserved it, and establishes the culture ofbowing to the authority, thus using those key words to wage into what he intends and hides, thereby stressing his superiority and greatness, he says: "congratulations should fall among the equals, and be only exchanged among the peers, cannot be met by love and serenity measures"(ALMA'ARRI, 1982, p. 73)

Apology for non-praising is consistent with AL- MA'ARRI cleverness, and reveals a case of alienation,so he invents a style that helps him escape the chains of power and authority, and rebels against the passivity of reality, to get rid of the prison he imposed on his life, by resorting to the symbolic anecdote language with indicative intensity.

\section{Alienation and anecdote language and symbol: between the absence of self and itslocalization:}

If AL- MA'ARRI lived a harsh experience of alienation,yet at the same time he pleaded by his wisdom to live effective presence in the language, its obscure and strange words.

He sees himself as not qualified to turn tothe praise of power's men ,his fellows and peers are bearersof sticks, or those whoare anonymous, he says: "there is great difference between the unknownwho usecrutches; and between the honorable people who bear the badges, and the people of powers and advices" ( AL- MA'ARRI, 1982, 53 )

AL- MA'ARRI embodies, however, the alienation fact which he sees in two things: imprisonment of blindness, and who has beengoverned by the stick and crutch, and patterns of a prisoner's feeble body imprisoned in his home, so the hidden is revealed using the plural and the third person pronoun, through the frequency of correlation between the following words:

Crutches -nobodies - AL- MA'ARRI (the Blind)

Notables - Badges and flags - the praised power.

AL- MA'ARRI says: "my peers are those whocarry walking sticks that help themin their movement and walking, sit in the remote place,and if I mistook that, my peer is DHUL bin DHUL (namely, who is nottraceable, and whetherhe wasof humans or non - humans), or he is bin BEE (expressing the lost, representation for the non-existent) (ALMA'ARRI, 1982, 85-86 )

On the other hand, the prison of fear surrounding AL - MA'ARRI reveals a disordered situation of alienation attributed toto political seditions, andout of those with condescending power that tend to marginalize, eclipse and excludethe other.

"AL- MA'ARRI made it difficult on himself so he chose the difficult to say or resister for himself that the harm inflicted him, his blindness, did not prevent his star from becoming bright, and he was not like the rest who were blind and satisfied with little knowledge"(SAMERRAEI, 1999, p. 15)

It is strange that AL- MA'ARRI was not satisfied with one example inrelating his narrations, both stories show that those who assume power through praisingand commendation of the low class people would eventually be exposed to punishment.

These stories served as a framework FOR AL- MA'ARRI,to tell what heharbors, the first tells the story of a great lion of the jungleanimals who gained agreat hunting, thus animals came congratulating and bowingout of fear.The male mouse advanced for congratulation, the lionturned angry, and allowedfor a catto punish the mouse as itsnature would elicit of evil and harm.

There is no doubt that the conditions at the time of AL- MA'ARRI were suitable for such symbolic gestures, and suggested a policy of violence and limited freedoms, devoid of human emotions, even in the expression of praise and commendation,the act of congratulations was from the those unqualified to cope with it, so actor deserved punishment, and it is strange that the type of punishment was physical extermination (murder).

The rat says between the jaws of cat:

"What is my fault! To be eaten in the vicinity of the great lion".

Some of the soldiers blamed and scorned it by saying:

"Youqualified yourself toa speech: you were not eligible for, soyou were counted among theignorant and fool" (AL MA'ARRI, 1982, 79 ). 
The same scene is repeated in another story, and our question is: "Why this insistence from AL- MA'ARRI on this same paint, regardless of its different and multiple characters. It is certain that this presence would contribute to integration of AL MA'ARRI with the issue that worried him; so, onlooker to overlapping of the stories, will confirm that alienation is the most important catalyst in the process of correspondence. The second story comes under the previous frame;its hero is one of thebirds of prey which came back to its young birds with an antelope, all birds kept silent,except one small sparrow.

The wild bird says to a falcon near it: "whois this fool who dared to speak in my presence? "(AL- MA'ARRI, 1982, 81) The conscious state suggested by the two stories won't stop usat the spatial alienation as far as it expresses an internal suffering and stressful psychological distress, and exhibits the contradictions, so,AL- MA'ARRI was concerned parableturned aroundtrifle characters with low social status, poverty and deprivation.

The two stories suggested exaggerationin taking caution and alertness when somebody advances the act of praise, as well as bears collision signals with its surroundings,and most likely that AL- MA'ARRI feared punishment of thosepraised, so he would receive what the rat and young bird had received.

AL- MA'ARRI disputed, in his writings to his time characters, with two matters, revealing counter paradoxes with him: hegemony of self and its centrality, elevation of the values of self - action, andreach a stage that worriedAL- MA'ARRI and punished himself severely, and turned tohimself where he imprisoned himself in his house, calling himself the prisoner of two prisons.

The other thing appears in his respect to human thinking, and social communicationwhere he used correspondences a means to contact others, through his letters.

Thus, AL- MA'ARRI took of praise as amulet to protect himself, and this incentive preliminary rendersthe other to listen to the rebellious opponent without receiving the meaninghidden behind the word. However, ALMA'ARRI resorted to symbolic codesusing animal masks; to present a case of alienation, that is to say ALMA'ARRI wasthe rat, and the young bird, and the authority was the stronglion, and the bird of prey.

\section{Deuteronomy and Alienation:}

In this letter, AL- MA'ARRI tried to fade his presence, for the privacy of the guest addressee, and the political host, and particularity of the epoch.

Since the praised are two, praise formed by Deuteronomy, so, AL- MA'ARRI language exercisesthe alienation when it touches the reality and approaches its characters to reach his goal, where he says: "As for the two revered masters, may God intensify the light of days in their presence,they are unequal to the twoyellows (gold and saffron), though one is a perfume, smelled and sniffed, and the other a jewelry possessed and money expended, yet, the two mastersare not similarity and likeness are not limited to them, and the fragrance value and golden preciousness, they are most valuable and precious, most elevated and the highest in degree.

Yet they are, in guidance, like two moons, and their justice and equity like that of the two Omar(s) age (OMAR BIN AL KHATAB, and OMAR BIN ABDL AZIZ)... and in guidance for the walker astwo night stars. They cannot be described as horse runnersin the field of kindness and liberality, not in the field of betting and chivalry" (ALMA'ARRI, 1982, 56)

Reverence bypraise and self-atrophy of AL- MA'ARRI self and its dwarfism would most likely reveal the remarkable presence of AL- MA'ARRI in his narration, and real absence of the praised through hiding their names and titles, and he was satisfied to denote them by words like: father of (somebody) and the guest.

It is no secret that the environment harbors contradiction and repulsion, such an environment must have clear marks on the power associatedwith masks closely related with itsfacts, or with people who were known as seniors of their time, when he described them to take advantage in the previous likening:

In their superiority, they are not equaled to the two yellows.

Ultimately, in guidance they are two moons.

And at night,they are guiding stars for the night walkers.

They are the two springsbywhich people enjoy prosperity, growth and yield.

They are the two HANTAFAN and ZHAHDAMAN, meaning ZHUDUM and KURDUM, of BANI ABS, and it's not strange that they have built their honor on (RAHAQ, ABAS and ALRAHAQ): injustice and wrongdoings.

The dual verbal express also alienation of the word and idea, AL- MA'ARRI resorts to light words, and incites defamation and exposure associated with meeknessin addressingthe powerpoles, as they are seem fromthe last verbal duality linked with people's fatigue,claim of their lives, surround them with injustice andphysical extermination. 
And so in AL- MA'ARRI communicative deedwhere he intensifies the mysterious language and thorny method, in which he reveals the disadvantages of dominant power, with words deemed asmasks, sothe charactershe referred to in the dual verbal tend to evil and excite horror.

Before the poverty of MAARAT AL-NU'MAN,miserable existence, hunger and life hardships of its people, ALMA'ARRI condemns the power when he likens it (to the two springs, green and fruit yielding, fertility, growth and welfare to people), so, originally the power has to ensure decent life to people,yet the matter doesn't come true and thus weal would transform to unfounded hopes and illusions in the place,MAARAT $A L-N U^{\prime} M A N$, whereALMA'ARRIinstills grief through sarcastic pungent images for the situationto which people and place have been through. AL- MA'ARRI continues his interaction with the factsof environmenton which real life impinged, so he resorts to language and symbol power,and here praise and commendation for the two masters as being two springs imparts the people with sorts of fertility "may God guards the two spring months, and what I mean by two months are known as two crescents in the year, but I wanted April and its brother, the truth abounds to whoever solicited it, they are two springs, bring along welfare, the first yields fruits and the other gives out flowers" (AL- MA'ARRI, 1982, 92-93 ), it's of paradoxes manifestations that enlarges, to suggest more cracking in the relation between the praiser and the praised, thus exaggeration reveals that the praiseddoesn'tnot fulfill their duty and deserve no praise at all, but praise was meant to awakenresponsibility and vigilance.

\section{Migration of the unnamed masterand wishing the impossible:}

After of what passed of his narration correspondence, AL- MA'ARRI reveredthe migration of the unnamed master to the Roman Crowned King by authorization from SHEBL $A L D A W L A$,this migration is more like a diplomatic embassy, which aims in its manifested purpose to subdue the war, redeem the captives, and securethe roads.

Here AL- MA'ARRI employs all his different knowledge in elucidatingthe psychological emotion and concern, where man suffers and this matter is reflected on everything surrounding him. Thus AL- MA'ARRI blesses this migration outwardly; this migration that the person in charge will gain from it happiness in in this world, while the afterlife whales will pray for him.

Here, comes the value of place, and the linkage of AL - MA'ARRI with his MAARAT AL-NU'MANand his hope for the stability of the place by its people, so if the migrationof OMEROEE AL QUEESbrothers of KINDA to stir up evil and ignite the war and strife, the migration offather ofnobody,was in the interest of the people and country, "he freeda captive, or rermedied in his custom a broken man" (AL- MA'ARRI, 1982, 95)

In the subject of migration, the letter included extensive narration, so AL- MA'ARRI stimulatesthe activation of his knowledge tools; with the aim to resurrect life in the place,thus the blessing of this minister, who is resolute to make reform on saline water where it turned fresh and pure like honey, or to make the ship moves on land, and illuminate like beacon at the hand of a hasty and rapid, or carried away by the blowing wind as it carried BALQIS throne, yet all this will not prevent the depletion of water and running the ship on land or flying in the air, to settle the inhabitants of sea of fish and whales by the blessing of (nobody)entertaining safety and security... (AL - MA'ARRI, 1982, 99-100)

And this reflects the depiction of place to which AL- MA'ARRI belonged, but it is a strange place where fear and sedition instigation and insecurity prevail, and things run the otherwise way.These strange scenes, which are like the impossible, give rise to questions for lacking of psychological harmony:

Do whales live far off the water?

Do ships move on land?

Does salty water turn into filtered honey in moments?

And, were these images effective and protective tools that illuminated dark spots in the history of the dark political and historical stage, in which appears the fear of AL- MA'ARRI from real collision with those he meant.

Once again, the place reacts anew when fathernobody achieves his need from migration and his desire, hence he became familiar success, and the water settled down, and "hope replaced the despair, so people characters straightened up, and knew about the lies and nonsenses, and avoided the way offalsehood and suspicions" (AL- MA'ARRI, 1982, 104 )

This migration,in the apparent talk of AL- MA'ARRI,reveals the will of power action, and raises the value of work attributed to the praisedand the establishment of this action in being positive behavior, so it can bring in good to the place and its people, and by these actions will silence the formidable exhausted voices, voices of defeat, failure, lies and nonsenses by the voice of accomplishment and change and realization of welfare. A new image dominate by which AL- MA'ARRI condemns the age and its corruption,as to reform the situation is almost impossible for the strange scenes documented by the place, and embodies the true sense of lacking safety where and fearing the coming, represented in the sense of conspiracy on the place and people . 
And, hope for the impossible is contracted from humans to stone, where the situation of paralysis and suppression pushed the nature towards dreaming and wishing, so AL- MA'ARRI resorted to the humanizingthe nature to imply the power of vocabularies and their impact on the state of surrender, weakness, sufferance, pain and the unification of nature with the subjects . "It seems from such fantasies, that hadn't occurred to AL- MA'ARRI, except for clothing and money, that the Kingdom of Aleppo, at that time, was suffering from economic hardship, and that the purpose of embassy was to secure the commercial routes"(ABBAS, 1/72)

The mountains would wish to have what falls in the two white years with the greenery interposed, i.e. arid) which would turnby Divine power to silver, so it will be carried to sultan palace to be distrusted by the Sultan to the patrons, and brign about the wretched happiness, and the narrow alley prays to God- whose ability is evident- to widen it, and the hill be a food plate from which the hungry would eat comfortably and conveniently (AL- MA'ARRI,1982, 105107 )

\section{Conclusion:}

The letters of AL- MA'ARRI,depicted stations of his life, and showed the relationships that linked him to the levels of the target audience, and confirmed his presence by self, effective and interacting with its external surrounding, and all of that and the soul had lived its prisons and internal confinement.

In this letter, AL- MA'ARRI tried to deny the value of himself, despite being known in his age, and to praise the people of power just for affectation and wiliness, but at the same time did not mention their names, and thisclear concealment of their names denoted their corruption and lack of action and bad erain which people complained of poverty and hunger, and most importantly, the lack of security and feeling of fear.

In his isolation, AL- MA'ARRI wasgentle to people, seeking their interest, and calling for setting right what was corrupt, using somehow ambiguous language, yet it concealed a deep philosophy emanating from a soul that delved deeply in the universe and its secrets .

\section{Sources and references:}

ABDEL RAHMAN, AISHA, (1972) with ABI AL ALA' in his life journey, DAR AL-KITAB AL-ARABI: Beirut.

AL-ALAYLI, ABDULLAH (1981), AL- MA'ARRI the Unknown "Journey in his Thought and Psychological World", AL AHLIA Publication and Distribution, Beirut.

AL- GHATHAMI, ABDULLAH, (2014), Cultural Criticism (Reading in Arab Cultural Patterns), ed. 6, Arab Cultural Center, Casablanca, Beirut.

ALMOHAMMADI, ABDELQADER, (2008), Alienation in the Islamic Sufism, ed. 1, House of Wisdom.

AL - JABRI, HASSAN (2005) Contemporary Man between the demise of civilization and his alienation. A Study in the Dialectic of Fear, ed. 1, Dar MAJDALAWI for Publication and Distribution.

ALJAMAEE, SALAHEDDIN (2007), Psychological and Social Alienation, its relation with the Psychological and Social Consensus, MADBOULI Bookshop, Cairo.

AL- MA'ARRI, AHMED BIN ABDULLAH, (1982), RESALAH ALHANA', investigated by: KAMIL AL-KILANI, ed. 4, DAR AL-AFAQ Publications; Beirut.

AL- MA'ARRI, AHMED BIN ABDULLAH, (1982), the letters of ABU AL ALA' AL- MA'ARRI, investigated by: IHSAN ABBAS, ed. 1.

ALQAFTI, ABU HASSAN JAMAL EDDIN ALI, (1965) news of narrators on the clever grammarians; quoted from: the book of introducing the ancients to ABU AL ALA', complied and investigated by: MUSTAFA SAQQKA et al., National Publishing and Printing House, Egypt.

ALSAMERRAI, E (1999), Studies in the Heritage of ABU ALA' AL- MA'ARRI, ed. 1, Dar AL DHIAA Publication and Distribution, Jordan.

ANIS, IBRAHIM et al., (1972), Al WASEET Dictionary, ed. II, Arabic Language Academy, Cairo.

DHAIF, SHAWQI, (1990) the Age of States and Emirates, ed. 2, Dar Al MA'ARIF: Cairo.

HUSSEIN, TAHA, (1977) Renewal of ABI ALAA memory, ed. 9, Dar Al MARREF, Cairo. Consideration of political situations in this era can be seen in the following books:

IBN FADHL AL-OMARI, (1965), MASALEK AL EYSAR; quoted from the book of introducing the ancients to ABU AL-ALA, complied and investigated by: MUSTAFA AL-SAQQA et al., National Printing House, Cairo, National House for Printing.

IBN MANTHOOR, ABU EL FADHL JAMAL EDDIN, (w/o date), LESAN AL-ARAB, DAR SADER, Beirut.

IBN TAGHAREE BARDI: JAMAL EDDIN ABU AL-MAHASEN, AL-NOJOOM AL ZAHERA in the kings of Egypt and Cairo (1963), the Ministry of Culture and National Guidance: Cairo, vol. 2, ATTABARI: 
ABU JAFAR MUHAMMAD IBN JARIR (1960), history of messengers and kings, author: MOHAMMAD ABULFADL, DAR AL MARREF, Cairo, vol. 9, and IBN KATHEER, IMAD EDDIN ABU AL FEDA (1995), ALBEDAIA \& ALNEHAYA, Dar AL FEKR, Beirut, vol. 11.

MAKKI, AL ABBAS, (1965), NOZHA AL-JALIS, quoted from the book of introducing the ancients to ABI AL ALA', compiled and investigated by: MUSTAFA AL-SAQQA et al., National Publishing and Printing House; Cairo.

RAJAB, MAHMOUD (1993), Alienation "Biography of the Term", ed. 4, Dar AL MA'AREF, Egypt.

SHATA, ASSAYYED, (1984), Theory of Alienation (From the perspective of sociology), ed. 1, ALAM ALKOTOB. YAQOOT AL-HAMAWI, SHEHAB EDDIN ABU ABDULLAH, (1991), Scientific Book House; Beirut. 